\title{
OBITUARY
}

\section{IN MEMORIAM IGOR DE RACHEWILTZ}

(1929-2016)

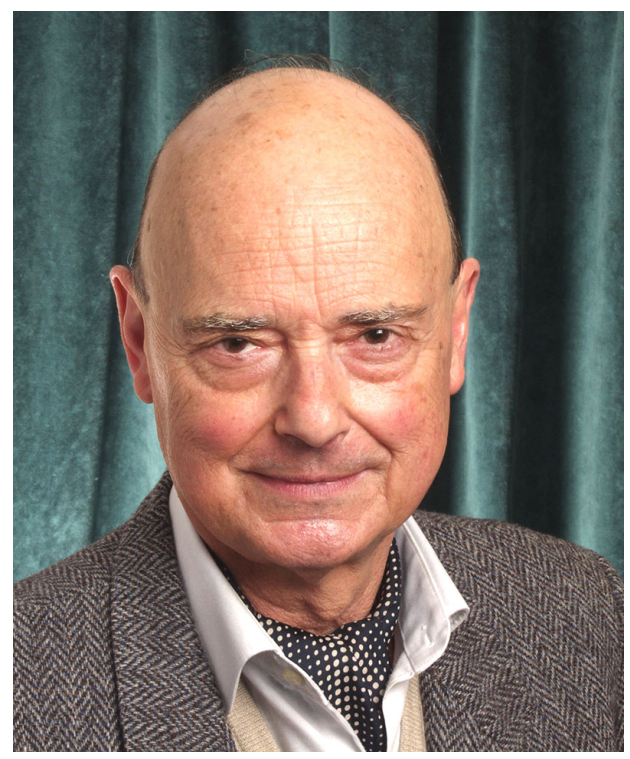

Source: http://www.eastasianhistory.org/

In the post-postmodern world it is a commonplace that the broadening academic horizon and mass production, along with the digitised publication of scholarly works, force researchers to engage in ever more focused and specialised topics and by this the classical type of scholar, the universal philologist is slowly becoming extinct. Yet those of us who have been lucky enough may still know some of the representatives of this sort of professors, and knowing their rareness makes it even harder to learn that someone of the already few ones passed away. Igor de Rachewiltz was undoubtedly a perfect archetype of the open-minded academician driven by a strong desire to make people - scholars and the wider public alike - understand his chosen field better. His letters written with his elegant handwriting, dated already in the digital age, take us back to a time when not only the information itself, but the style of communication was also a form of art per se, and thus they are now meaningful relics to those who were fortunate enough to receive some of them.

He was born into an Italian-Russian family with a very complex family tree and on the maternal side with a story of ancestry about an alleged Central Asian descent, a Tatar princess from Kazan who was thought to be connected to the descendants of the Golden Horde. Though the story remained unconfirmed in Igor de Rachewiltz's life, this motif, as he admitted in an interview shortly before his death, was 
most likely influencing him in a subconscious way to choose his vocation. "Prince Igor" - as many of his colleagues and friends called him after the protagonist of the mediaeval Russian literary masterpiece depicted also in a famous Russian opera and drama - started his career in Italy. After an unfinished law school detour (with an objective to utilise his already good knowledge of the Chinese language in diplomatic service) he turned back to his childhood interest, that is, the letters and languages as well as the ancient cultures of Asia. Still in Italy, he was given the chance to meet Ezra Pound in the house of his brother who married the daughter of Pound. Pound, who also admired Chinese culture and had translations of Chinese classics, supported him with books.

Later, after some years of learning of Japanese and Chinese, he started his oriental studies at the Instituto Universitario Orientale in Naples under the guidance of Professor Giuseppe Tucci. The subsequent step in his life was moving to Australia in 1955 after receiving a $\mathrm{PhD}$ scholarship offered by the Australian National University in Canberra. He earned his $\mathrm{PhD}$ in 1960 and remained a faculty there for his entire life.

His chosen research field covered a large area of oriental studies, including the political and cultural history of China and Mongolia from Genghis' rise to power until the end of the Yuan dynasty; political and cultural contacts of the same period between East and West and most of all Sino-Mongolian philology. These matters of interest are extending far further than one can safely fit in an academic career, yet he was able to contribute to practically all their vertices.

There is no place (and probably need) for citing his manifold works here. A good bibliography of them was included in the Festschrift "The Early Mongols" published for his 80th birthday (Volker Rybatzki et al. eds, The Early Mongols: Language, Culture and History. Studies in Honor of Igor de Rachewiltz on the Occasion of his 80th Birthday. Bloomington, Indiana, 2009. Indiana University Uralic and Altaic Series 173). He had several publications after that, too, which are available at the Australian National University website along with a short biography. A special mention should be made of a field he probably loved above all. He was fascinated by the supreme Mongol intellectual achievement of the times he was investigating, that is, "The Secret History of the Mongols". This work is not only one of the main historical sources ever compiled about the time of the establishment of the Great Mongol Empire, but also the richest and apparently inexhaustible source for linguistic and philological scrutiny. One academic highlight of Igor de Rachewiltz's fruitful scholarly life was unquestionably the publishing of the hitherto unsurpassed critical edition of this most important Sino-Mongol historical work (after multiple earlier editions also by him). Lately, together with Professor John C. Street of the University of WisconsinMadison, he made a shorter version of his translation aiming at a wider readership and made it freely available online, helping readers interested in Mongolian history and culture to get a deeper insight into this masterpiece.

Earlier last year in a personal communication he mentioned that in 2015 he started preparing a translation of the Mongolian version of the Geser Khan story (1716) into an - as he put it - "easy and readable English" for the general public, and just like 
in the case of the last Secret History edition, with only a basic commentary. By the age of 86 he decided to cut down his philological research related to Mongol and SinoMongolian studies considerably and donated all his books on the subject to the Ferdinand Verbiest Institute in Leuven, Belgium. He planned to have more time for translation, and even in mid-2016 he was full of plans, although he admitted that at his age it would be timely to dedicate more time for his own amusement as well, for which he was given no long time.

Igor de Rachewiltz will not only be missed as an outstanding member of academia, but also as the ever helpful teacher and cheerful friend.

Ákos Bertalan Apatóczky 